\title{
Evaluation of Impact of Cost Information System: A Case Study of Credit Institution and Construction of Houses for Navy Employees
}

\author{
Patrícia Dos Santos, Marcelo Albuquerque De Oliveira, Gabriela De Mattos Veroneze, Marcelo Silva \\ Pereira
}

\begin{abstract}
The objective of this work was to evaluate how Federal Government's Cost Information System (CIS) contributed positively in the decision-making of cost management in the Caixa de Construções de Casas para o Pessoal da Marinha (Credit Institution and Construction of Houses for Navy Employees). This research proposed the hypothesis that the variables of the Cost Information System (CIS), classified by this work in System Quality (SIST-Q), Information Quality (Q-INFO) and Perceived Utility (PUTILI) generate positive effect on decision making in the more efficient allocation of expenses at federal autarchy. The study was carried out through a "Case Study", using descriptive statistics and the Confirmatory Factor Analysis technique, based on an information systems assessment model widely studied in the literature, proposed by Delone and Mclean. The survey results suggest that there is a moderately consistent scale for measuring the effectiveness of the Cost Information System (CIS), which is made up of the three latent variables: quality of the system, quality of information and perceived utility. It was evaluated that the CIS does not produce results for cost management because the management information extracted from the system is not used for decision making by managers. Additionally, a performance indicator was suggested to monitor federal autarchy's cost management. This work suggests that new research be carried out with other organizations that use the CIS in order to better understand the needs of organizations regarding the adequacy of the System to their needs.
\end{abstract}

Index Terms - CIS, Evaluation, Impact, Key Performance Indicator (KPI).

\section{INTRODUCTION}

\section{A. Overview}

Brazil has been directing efforts, for some decades, towards a change in public service mentality. Transparency, economy, efficiency, effectiveness and computerization to improve processes are targets sought by public management in order to adapt to new management parameters [1]. Such changes seek to harmonize with a trend among many countries that have adopted technologies and management tools, already proven effective in the private sector, in order

\footnotetext{
Published on August 31, 2020.

P. Santos, Federal University of Amazonas, Brazil. corresponding e-mail: patriciasantos $u$ ufam.edu.br).

M. Oliveira, Federal University of Amazonas, Brazil.

(e-mail: marcelooliveira $\omega$ ufam.edu.br)

G. Veroneze, Federal University of Amazonas, Brazil.

(e-mail: gveroneze ${ }^{a}$ ufam.edu.br)

M. Pereira, Eldorado Research Institute, Brazil.

(e-mail: marcelo.pereira $\omega$ eldorado.org.br)
}

to become more efficient and effective. Two relevant initiatives are listed to improve the management of public resources, which are: adoption of management accounting and strategic cost control [2].

For authors [3]-[5] the most relevant initiatives taken in the managerial reform of Brazilian public management to improve strategic cost control were: Law No. 4,320 / 1964, which established that the public entity should allocate the proceeds of its taxes to the cost of its activities; Decree-Law No. 200/1967, which stipulated that "accounting should determine the costs of services in order to show the results of management"; the 1988 Federal Constitution of Brazil that institutionalized the efficiency law; Law 8,666 / 1993 which instituted rules for public tenders and contracts; the creation of the Ministry of Administration and Reform of the state in 1995; tax liability law 101/2000; the Publication of Brazilian Accounting Standards Applied to the Public Sector (BTAS-T), resolutions No. 1,128 / 08 through No. 1,136 / 2008 of 11/25/2008 and; Judgment No. 1078/2004, of the Federal Court of Auditors, which determined arrangements that the federal public administration have a costing system to evaluate and monitor the budgetary and financial management of the management.

In order to adapt to the international trend in cost management and the guidelines presented in the legislation, Brazilian public management sought to constitute a conceptual model that would serve as a tool for cost control and that would objectively subsidize the decision-making process in the federal public sphere.

The Cost Information System (CIS) is a technological tool that was developed in order to allow analytical consultations of costs of various dimensions and extracting data from three structuring systems: the Integrated Financial Administration System (IFAS), Integrated Administration System of Personnel (IPMS) and the Management Information and Multi-Year Planning System (MPPS) [6]. The CIS was managed, until 2010, by the Ministry of Finance. The main theoretical bases of the referred system were the doctoral theses of the managers, Nelson Machado and Victor Branco de Holanda, servants of that Ministry [7].

The Cost Information System (CIS) was developed in order to provide an efficient cost management, generating an evaluation of the quality of the expenses that would turn into positive results for the public management. Additionally, cost management with the help of CIS's technological resources can contribute as a support tool in the process of preparing and executing the annual budget of entities that are members of the public power [8]. 
It was observed during the research, that there is no monitoring of the results of the implementation of the CIS and of the management of costs. Therefore, this work developed a Key Performance Indicator (KPI) for suggestion of adoption by the Caixa de Construções de Casas para o Pessoal da Marinha (Credit Institution and Construction of Houses for Navy Employees).

Based on the aforementioned reflections on public management, it is expected that the study carried out, when evaluating the Federal Government Cost Information System (CIS) and, when suggesting the adoption of a performance indicator, will contribute to increase strategic cost management at federal autarchy without loss of quality for users of its services. In the academic environment, it is expected that this work will contribute to fill the gap in studies that address this theme and, in particular, the efficiency, effectiveness and effectiveness in public management.

\section{B. The Hypothesis}

In view of the question-problem, this work raised the following hypothesis, whose aim is to achieve the objectives listed in item 1.4: the variables of the Cost Information System (CIS), classified by this work in System Quality (SIST-Q), Quality Information (Q-INFO) and Perceived Utility (P-UTILI) generate a positive effect on decision making in the more efficient allocation of expenses at federal autarchy.

\section{Problem Statement}

The research was focused on to evaluate how the implementation of the Federal Government Cost Information System (CIS) affect the decision making of cost management and proposing a performance indicator Key Performance Indicator (KPI), for monitoring cost management.

The present study was characterized as a field research, analysed by the case study method, for the evaluation of the impact of the Federal Government Cost Information System (CIS) in the cost management process of Caixa de Construções de Casas para o Pessoal da Marinha (Credit Institution and Construction of Houses for Navy Employees) that will be called throughout the research, Federal Autarchy.

The Credit Institution and Construction of Houses for Navy Employees, object of the present case study, is a Federal Autarchy. The main activity is the offering of real estate financing and the secondary activities are the offering of real estate loans and real estate advice [9].

\section{LITERATURE REVIEW}

\section{A. Strategic Cost Management (SCM)}

According to Berto and Beulke, the best definition of cost is a monetary expression that must have a lower final, good, saleable quantity of products / services to replace, at the end of each operational cycle, a greater initial quantity of inputs and consumptions of the next cycle [3]. According to Blocher et al. the cost occurs when a given resource is used for some purpose and it is grouped according to similar characteristics [10].

Strategic Cost Management (GEC) arose from the growing importance of cost information, from the need to serve more complex information technology systems for decision making and as a tool for maximizing profits. GEC has become indispensable not only for private organizations, but also for non-profit organizations. GEC aggregates not only the analysis of processes in which value is added, but the entire production chain [11].

GEC started to have a wider scope due to new management approaches. Just as new technologies have transformed the competitive environment. Managers look for quick and efficient responses to make decisions, which need to be more and more accurate and quick. In public administration, in particular, delivering quality services to citizens does not escape the need for the adoption of differentiated practices and the adoption of management technologies. According to Porter the best product or service is the one that adds value to the customer [12].

\section{B. Strategic Cost Management in International Public Management}

In the international context, some countries were motivated to adopt a cost control system as part of a comprehensive reform and, for others, to generate information for improving public spending and assessing tax risks. The countries Australia, New Zealand and the United Kingdom stood out on the implementation of cost management. The Australia is the object of study for the implementation of the Brazilian cost information system. The United States of America and Canada have implemented the accrual basis, without applying it to the entire budget [7].

The countries that stood out the most in strategic cost management and their main initiatives are listed in the following: Australia (comprehensive tax reform); Canada (partial reform); Denmark (cost control system and competence regime); United States (partial reform); Netherlands (cost control system without adoption of the competence scheme); New Zealand (comprehensive tax reform); United Kingdom (cost control system and competence regime); Switzerland (cost control system and competence regime); Sweden (cost control system without adoption of the accrual basis).

Two important observations in the international experience in cost management are a profound reform seeking greater efficiency in management and public spending and the commitment of all federated entities to the objectives of the project [13]

\section{Cost Management in Brazilian Public Sector}

In 2005, the first steps were taken towards the effective adoption of a cost information system in public administration with the creation of an inter-ministerial commission for the study and guidelines for the creation of a cost system [2].

Subsequently, for the implementation of a cost system in federal public management, several steps were taken, such as the institution of the Technical Chamber of Quality of Spending (CTQG), debate workshops and in 2009, an initial version of the Information System of Federal Government Costs (CIS). In 2011, cost information management for system management was established and, in March of the 
same year, Ordinance $\mathrm{N}^{\circ} 157$, creating the CIS [14].

\section{The Cost Information System (CIS)}

The Federal Government Cost Information System (CIS) is a computerized cost measurement tool, called a "theoretical-conceptual model" that captures information from transactional systems, called Federal Government structuring systems and integrates them into a single database [15].

A conceptual model is a written or graphic representation of an environmental situation. The objective of the CIS is to determine the costs of programs and units of the Federal Public Administration to enable the monitoring and evaluation of the budgetary, financial and patrimonial management of the public sector, its main purpose being to support the decision-making process [15]. Santos illustrated in his article the dynamics of the Conceptual Model of the Cost Information System (CIS], as shown in the following Fig. 1.

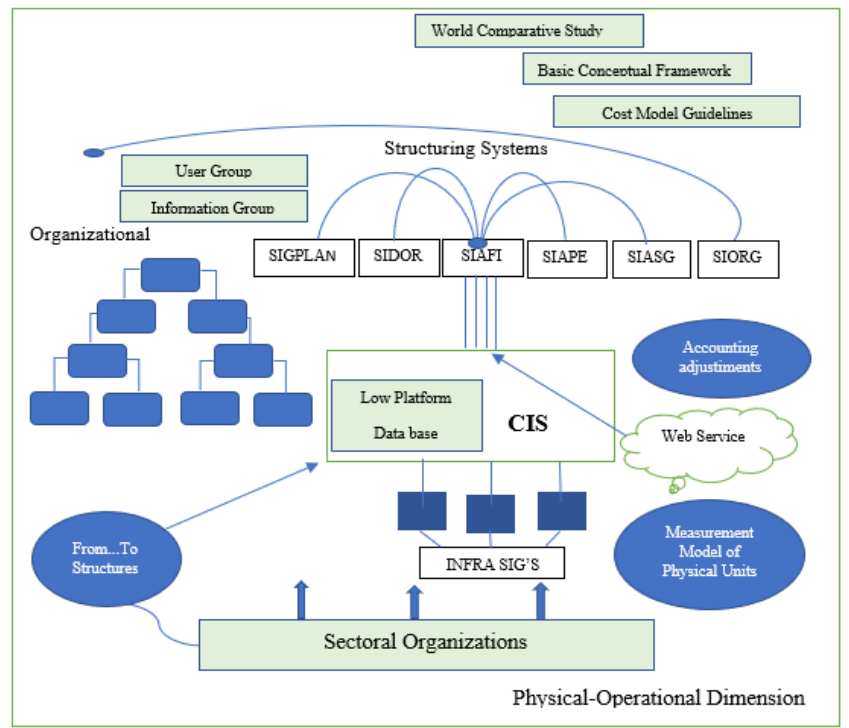

Fig. 1. Adaptation - Conceptual Model of the Federal Government Cost Information System.

The Public Sector Cost Information System (CISSP) is supported by three elements: accumulation system, costing system and costing method, in accordance with the Brazilian Technical Accounting Standard (NBC-T) 16.11.

The operational cycle of the Cost Information System (CIS) develops with the accumulation of costs per process, in which public services are performed continuously and the costs accumulated periodically in the organizational units. The costing method applied is absorption, in which indirect costs are allocated to administrative units, provided that the consumption of resources is significantly related to public servants (apportionment criterion) [14].

\section{E. Monitoring of Cost Management by Performance Indicators}

Key Performance Indicators (KPI), are metrics developed for monitoring diverse processes, tasks, projects or organizations. These are efforts undertaken with the aim of obtaining management results [16].

Performance indicators (KPI), reflect the critical success factors of an action, sector or the organization as a whole.
Each organization, both in the private sector and in the scope of the public service, uses the KPIs that best portray and evaluate the activities developed. Performance indicators must reflect the organization and must be essential for its development. The main performance indicators must be quantifiable and measurable accurately [17].

Monitoring by means of performance indicators (KPI) in Public Management is not new. However, due to the peculiarities of the public service, properly maintaining a management system that assesses results and engages managers and employees, in general, is not very easy [18]. In general, public organizations are unique in the service they provide, but at the same time, what best identifies them is that they meet collective and public concerns. It is essential for effective management that these organizations work with performance indicators, especially those that serve the public directly [19].

\section{F. Information Systems Assessment Models}

Delone and Mclean [20], [21] developed the model in order to identify aspects of quality that contributed to the success of an Information System. This model describes the factors that can influence an organization's information systems. According to the authors, two aspects are critical to the performance of an information system: the quality of the system itself and the quality of the information that is produced by this system [21]. The two factors described influence the use of the system and the users' perceptions, impacting the individual and causing consequences for the entire organization [22]. Delone and Mclean [20], [21] carried out research involving several empirical studies and proposed, in 1992, a model of analysis of success factors of Information Systems (SI) [23].

The diversified impact studies aim to verify the results generated by management intervention actions, and the use of tools or changes made in processes. The impact is the end of the line of a system which is composed of, originally, in English, the inputs, outputs, outcomes and impacts, in Portuguese, inputs, outputs, results and finally impacts. We cannot confuse the impact with the result. The impact on a chain of results is the final stage of a cycle and highlights the change, indicators, benefits and / or harms of management interventions [24].

A chain of results from an impact assessment, according to the model presented by Delone and McLean [20], goes through the following steps: Inputs - Outputs - Impacts Outcomes. In 2003 the Model was updated, as shown in the following Fig. 2.

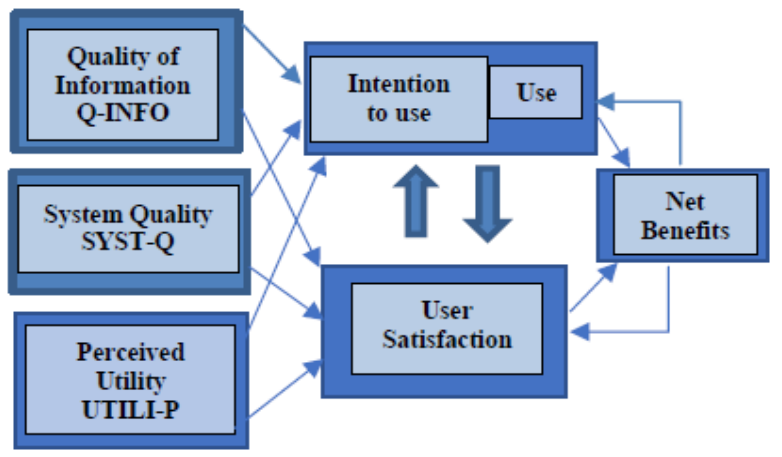

Fig. 2. Adaptation Impact Assessment Result Chain. 
In the updated model of Delone and Mc Lean for the evaluation of information systems is composed of the constructs Quality of Information, Quality of the System and, later, the Quality of Service was introduced. Also, the individual and organizational impacts were classified as net benefits, as shown in the above Figure.

The trend of organizations with results-based management and decision-making, based on evidence, created the need for stricter controls and identified an evaluation gap for the better development of the organization. As a result, managers started to seek to develop methodologies for impact assessments, which are becoming more rigorous and precise.

The impact assessment study model presented by Delone and Mc Lean [20] defines that the impact study is divided into six dimensions: quality of the system, quality of information, use of the system, user satisfaction, organizational impact and net benefits; determined by the interaction of three groups functionality, usability and utility [23].

In studies by [25]-[27] the study of impacts is conceptualized as the analysis of the consequences of some modification made in some process or company [24].

\section{G. Confirmatory Factor Analysis (AFC)}

For the evaluation of the Cost Information System (CIS) of the Caixa de Construções de Casas para o Pessoal da Marinha (Credit Institution and Construction of Houses for Navy Employees), the Confirmatory Factor Analysis (CFA) is a data analysis method that tests how well the measured variables represent a smaller number of constructs. The researcher must specify the number of factors that exist within a set of variables and on which factor each variable will carry a high load before results can be computed. Also, it must be able to assign variables to factors before obtaining any results [28].

CFA statistics is intended to answer how well a specification of factors aligns with the actual data and to group highly correlated variables into distinct factors. Each group in the CFA represents a set of highly interrelated variables that may reflect a more general evaluative dimension [28].

\section{Methodology}

The case study method was configured as the best method for directing this research. The case study can be defined as a research procedure that investigates a phenomenon within a given local context and that contributes to the understanding of individual, organizational, social and political phenomena [29]. The case study was conducted through fieldwork that adopted multiple tools for collecting primary and secondary data. This work was based on statistical theory, of quantitative character. The data were obtained through a structured questionnaire, were analyzed using the Likert and Likert type scales, using the Confirmatory Factor Analysis technique.

\section{A. Impact Assessment of the Cost Information System (CIS)}

The research was developed from the qualitative and quantitative approaches, the latter that deals with the collected data and the evidences, considering that everything can be quantified and translated into numbers, and opinions, and also provide information to classify and analyze them. The quantitative approach requires the use of tools and statistical techniques (percentage, mean, mode, median, standard deviation, correlation coefficient, regression analysis, etc.) [30].

The data was analyzed using the Confirmatory Factor Analysis technique. This technique analyzes whether the latent variables justify the respective observed variables and shows, if these constructs are correlated with each other, if one wants to assess the existence of an underlying scale [31].

To assess the impact of the Cost Information System (CIS) on the management of the federal autarchy, data collection was performed using several tools: interview with the manager, application of a research form, questionnaire for the workforce working in the financial areas and costs, and for decision-making managers. Data was also collected from the access to information contained in the Treasury Transparent website, of the National Treasury Secretariat (NTS). These tools were chosen in order to collect as much data as possible in order to generate reliable results that can be applied posteriori.

\section{ANALYSIS AND INTERPRETATION OF RESULTS}

The analysis and interpretation of the data was developed using qualitative methods through an interview with the manager responsible for the Cost Information System (CIS) and observation "in loco" not participating in the Federal Autarchy. Quantitative methods were carried out through a questionnaire and analysis of open data on the website of the National Treasury Secretariat (NTS). Thus, we sought to answer the research question and confirm or not the hypothesis raised by this work.

To achieve the objectives of the work, the following phases were covered: evaluation through a questionnaire, interview with the manager responsible for the CIS, nonparticipant observation and access to Federal Autarchy open cost data, on the NTS website.

In sequence, the data was tabulated, in order to be analyzed according to fundamental concepts of descriptive statistics, setting up a database in the spreadsheet editor (EXCEL 97). Finally, the evaluation of the Cost Information System (CIS) was conducted using the information systems evaluation model of Delone and McLean [20], [21] for a theoretical concept not directly observable, called construct.

\section{A. Evaluation Results Cost Information System (CIS) - Questionnaire Evaluation}

The population of the present study refers to the workforce of the Caixa de Construções de Casas para o Pessoal da Marinha (Credit Institution and Construction of Houses for Navy Employees), which totalled 156 in December 2019, and the Navy Finance Directorate (NFD) which totaled 207. The research was limited to testing as a sample the workforce working in the Finance department of the federal autarchy and in the cost sector of the Navy Finance Directorate (NFD) that work in some way with the Cost Information System (CIS).

The questionnaires were sent to the survey participants between the months of December 2019 and March 2020. 
The tool used to send the survey questionnaires was the survey administration application Survey, and Google Forms (Appendix 1). The questionnaire was designed in harmony with the information systems assessment model of Delone \& Mc Lean [21].

The universe of survey respondents was divided into four categories, with questionnaires being applied to the workforce of Federal Autarchy and NFD as follows:

a) manager with SIC access - head accountant, head of the financial department, in charge of financial execution.

b) manager without SIC access - presidency, executive board, advisors, heads of department, in charge.

c) user with SIC access - accounting and financial execution assistants.

d) user without SIC access - other components of the workforce.

The forms were applied to the workforce components of the Finance Department of the Credit Institution and Construction of Houses for Navy Employees. This sector is responsible for accounting, financial execution, treasury, insurance management and for managing the Federal Government Cost Information System (CIS). Five of the nine workforce components responded to the survey.

In order to measure more robustness to the survey in addition to the employees of the CCCPM's financial department the questionnaire was applied to the components of the workforce in the cost sector of the Navy Finance Directorate (NFD). NFD is a military organization belonging to the General Secretariat of the Navy (GSN) and which exercises, among other competencies, those of internal control, central accounting body, personnel payment and the cost system of the Brazilian Navy. Of the seven components of the NFD cost sector workforce, to which forms were sent, three responded to the survey, two of which were managers and one was non-manager.

The questionnaire was divided into three blocks: Block I Profile of respondents; Block II - Level of Knowledge about the Cost Information System and Block III - Interviewee's Perception on the Cost Information System.

In the Block I - Respondents' profile, most have postgraduate degrees, have worked for more than five years in the Brazilian Navy, the category is military, and they work in the organization's accounting or finance department. As for the position, 50\% are managers and 50\% are not managers.

In the Block II - Level of Knowledge about the Cost Information System, this research analyzed the level of knowledge of the workforce about the Cost Information System (CIS) and about the International Convergence of Public Accounting. It converges accounting standards in Brazil with international accounting standards, in order to modernize accounting procedures, adapting to international parameters and enabling the generation of information that is useful to support decision making and the accountability process and control for society [8].

Most respondents have already participated in an event related to the Cost Information System (CIS) or know if it is fully implemented. Two components of the workforce responded that they did not participate in any CIS-related event. The consequence of the lack of technical knowledge by a component of the workforce that operates in the sector responsible for controlling the Cost Information System (CIS) is considered relevant for determining the efficiency and effectiveness of cost management. Five people replied that they know that there is a performance indicator for the assessment of CIS. It was reported in an interview by the head accountant of federal autarchy, responsible for the CIS that there is still no performance indicator related to the cost system. All respondents responded that they knew what its relevance is to cost management in the organization. Six components of the workforce responded that they have knowledge about the International Convergence of Public Accounting and two responded that they did not have this knowledge. Five respondents replied that they are aware that the International Convergence of Public Accounting results in benefits for public accounting in Brazil and three components said they were unable to assess.

It was asked if the components of the workforce are aware if the Cost Information System (CIS) is easy to be accessed, operated and understood. Five components of the workforce answered positively 01 (one) employee answered negatively, 01 (one) was unable to evaluate and 01 (one) did not answer the question. All responded knew what a cost center was, which seems to oppose the first question, about participating in some event such as a course, lecture or seminar to receive guidance on the CIS.

In the Block III - Interviewee's Perception about the Cost Information System (CIS), the perception of the workforce about the system was analyzed, in order to measure the satisfaction of managers and users in relation to the CIS.

Most respondents consider the implementation of a cost control system to be "very useful" for public sector management and budget control. None of the respondents consider that the use of cost information as an instrument for evaluating the performance of federal public management is "very useful" and 50\% considered it "useful". Most respondents considered the cost system "useful" as a means of transparency regarding the qualitative and quantitative aspects of government programs. No component considered the cost system "not useful".

Most respondents believe that the implementation of the CIS is improving decision-making based on Strategic Cost Management. They believed that the data extracted from the SIC System has functionality, is accurate, and that the SIC is meeting its main objective of providing data for decision making. Some did not know how to answer whether the CIS has functionality or accuracy of information and whether it provides useful data for decision making.

The scale evaluation represents the direct and indirect effects of the latent variables among themselves. To answer the research problem, it was necessary to analyze whether the constructs Quality of the system (SIST-Q), Quality of information (Q-INFO) and Perceived utility (P-UTILI) are correlated with each other, constituting, for this research, a scale for the effectiveness of the System of Cost Information (CIS) [31].

For content validation, it was necessary to establish the attributes, constitutive and operational definitions of each variable item. The questionnaire items, as well as the latent variables and the observed variables are arranged, as shown the following table: 
TABLE I: QUESTIONNAIRE ITEMS

\begin{tabular}{|c|c|c|c|}
\hline & Item & $\begin{array}{c}\text { Variable } \\
\text { Latent }\end{array}$ & $\begin{array}{c}\text { Observed } \\
\text { Variable } \\
\end{array}$ \\
\hline 01 & $\begin{array}{l}\text { Knowledge if the Cost Information } \\
\text { System (CIS) was fully implemented } \\
\text { and being used }\end{array}$ & \multirow{4}{*}{ SIST-Q } & SIST-Q1 \\
\hline 02 & $\begin{array}{l}\text { If the CIS implementation is believed } \\
\text { to be improving decision-making based } \\
\text { on Strategic Cost Management }\end{array}$ & & SIST-Q2 \\
\hline 03 & $\begin{array}{l}\text { If you believe that the CIS is meeting } \\
\text { your main objective, which is to } \\
\text { provide data for decision making }\end{array}$ & & SIST-Q3 \\
\hline 04 & $\begin{array}{l}\text { Knowledge about the existence of a } \\
\text { performance indicator in the } \\
\text { Organization that assesses the results }\end{array}$ & & SIST-Q4 \\
\hline 05 & $\begin{array}{l}\text { Knowledge if the CIS is easy to be } \\
\text { accessed, operated and understood }\end{array}$ & \multirow{5}{*}{ Q-INFO } & Q-INFO1 \\
\hline 06 & $\begin{array}{l}\text { Participation in any event such as } \\
\text { course, lecture or seminar to receive } \\
\text { guidance on the CIS }\end{array}$ & & Q-INFO2 \\
\hline 07 & $\begin{array}{l}\text { A Key Performance indicator is } \\
\text { relevant for cost management in the } \\
\text { Organization }\end{array}$ & & Q-INFO3 \\
\hline 08 & $\begin{array}{l}\text { Believe that the data extracted from the } \\
\text { CIS System has functionality }\end{array}$ & & Q-INFO4 \\
\hline 09 & $\begin{array}{l}\text { The data extracted from the CIS is } \\
\text { believed to be accurate }\end{array}$ & & Q-INFO5 \\
\hline 10 & $\begin{array}{l}\text { The International Convergence of } \\
\text { Public Accounting is resulting in } \\
\text { benefits for public management }\end{array}$ & \multirow{7}{*}{ P-UTILI } & P-UTILI1 \\
\hline 11 & $\begin{array}{l}\text { Usefulness of CIS implementation for } \\
\text { the public sector }\end{array}$ & & P-UTILI2 \\
\hline 12 & $\begin{array}{l}\text { Usefulness of the cost system for the } \\
\text { budget process }\end{array}$ & & P-UTILI3 \\
\hline 13 & $\begin{array}{l}\text { The Cost information as an instrument } \\
\text { of public management control }\end{array}$ & & P-UTILI4 \\
\hline 14 & $\begin{array}{l}\text { The cost information as an instrument } \\
\text { for evaluating federal management } \\
\text { performance }\end{array}$ & & P-UTILI5 \\
\hline 15 & $\begin{array}{l}\text { Usefulness of cost information as a } \\
\text { decision-making tool }\end{array}$ & & P-UTILI6 \\
\hline 16 & $\begin{array}{l}\text { Usefulness of the cost system as a } \\
\text { means of transparency regarding the } \\
\text { qualitative and quantitative aspects of } \\
\text { government programs }\end{array}$ & & P-UTILI7 \\
\hline
\end{tabular}

As explained previously, This research applied the Likert scales of 05 (Five) points and the Likert Type of Three points were used as following: variables from 01 to 07 and from 14 to 17 (yes=2; no=1; I can't evaluate $=0$ ); variables from 08 to 13 (Very useful=5; Useful=4; Indifferent=3; Not very useful $=2$; No Use $=1$.

\section{B. Test and Validation of the Presented Hypothesis}

Hypothesis tests aim to provide a methodology that allows verifying whether a sample has evidence to support a hypothesis or not and which scenario is most appropriate within a collection of inferences [32]. For Montgomery and Runger the hypothesis test is a procedure that leads to a decision on a particular hypothesis and that uses information from a random sample from the population of interest [32]. In general, hypotheses are composed of only two premises, so that they configure a partition of the parametric space (or subspace of interest). The hypotheses are generally referred to as $\mathrm{H} 0$ (Aga-zero), which is the null hypothesis and $\mathrm{H} 1$ or HA (alternative hypothesis). These are represented by the following symbols [33]:

\section{H0: $\Theta \in \Omega 0$}

$\mathrm{H} 1:$ : $\Theta \Omega 1$, Where $\Omega=\Omega 0 \cup \Omega 1, \Omega 0 \cap \Omega 1=\emptyset, \Omega 0 \neq \emptyset$ and $\Omega 1 \neq \emptyset$

In item 1.3 , the hypothesis stated by this study is presented for confirmation, or not of its validity. Through the Confirmatory Factor Analysis, it was possible to calculate the levels of significance and reliability and for the casual relationships that comprise the hypothesis of this work.

\section{Average}

At first, the mean of the observed variables, derived from the constructs SIST-Q, Q-INFO and P-UTILI, was obtained.

Table VII shows the result of the average of the questionnaire responses on the variables: quality of the system (SIST-Q), quality of information, (Q-INFO) and perceived utility (UTILI-P), considering, from answer 01 to 07 and 14 to 17 the Likert type scale of 03 (Three) points, being yes $=2$, no $=1$ and $\mathrm{I}$ do not know how to evaluate $=0$. Question 09 to 13 on the Likert scale, of 05 (Five) points, being very useful $=5$, useful $=4$, indifferent $=3$, little useful $=2$ and not useful $=1$, according to the following table:

TABLE II: AVERAGE OF QUALITY VARIABLES

\begin{tabular}{ccc}
\hline \hline Variables & Average & Reference Scale \\
\hline 01 to 07 & 1,696 & $(2,1,0)$ \\
\hline 08 to 13 & 4,521 & $(5,4,3,2,1)$, \\
\hline 14 to 17 & 1,500 & $(2,1,0)$ \\
\hline 01 to 07 and 14 to 17 & 1,598 & $(2,1,0)$ \\
\hline \hline
\end{tabular}

\section{Variance}

In sequence, in table VIII, the variance of the variables SIST-Q, Q-INFO and P-UTILI was obtained. The calculation of the population variance is obtained by adding the squares of the difference between each value and the arithmetic mean, divided by the number of elements observed, as shown the following table:

TABLE III: RESULT OF VARIANCE

\begin{tabular}{cc}
\hline \hline Variables & Variance \\
\hline 01 to 07 & 0.361 \\
\hline 08 to 13 & 0.255 \\
\hline 01 to 07 and 14 to 17 & 0.467 \\
\hline 14 to 17 & 0.645 \\
\hline \hline
\end{tabular}

\section{E. Calculation of Standard Deviation}

Finally, the standard deviation was calculated. This is calculated from the square root of the mean of the deviations between the values and the mean of the data values squared:

TABLE IV: STANDARD DEVIATION OF VARIABLES

\begin{tabular}{cc}
\hline \hline Variables & Standard deviation \\
\hline 01 to 07 & 0.595 \\
\hline 08 to 13 & 0.500 \\
\hline 01 to 07 and 14 to 17 & 0.679 \\
\hline 14 to 17 & 0.791 \\
\hline \hline
\end{tabular}

\section{F. Internal consistency}

At another time, the confirmatory factor analysis technique was used to assess reliability and suitability. The reliability of the items in the SIST-Q and Q-INFO constructs was analyzed together, as shown in table $\mathrm{X}$, as they have the same response categories and, later, the P-UTILI. based on Cronbach's Alpha coefficient, the constructs presented the 
index, as following table:

TABLE V: RELIABILITY STATISTICS

\begin{tabular}{c|c|c}
\hline \hline \multicolumn{2}{c}{ SIST-Q and Q-INFO reliability statistics } \\
\hline Cronbach's alpha & Cronbach's alpha & N of items \\
\hline 0.122 & 0.122 & 9 \\
\hline Cronbach's alpha & P-UTILI reliability statistics \\
\hline 0.513 & 0.513 & $\mathrm{~N}$ of items \\
\hline \hline
\end{tabular}

The reliability of the items in the SIST-Q and Q-INFO constructs were calculated together because they have the same response categories, after excluding the items QINFO1 and Q-INFO2. And the reliability of the P-UTILI construct items, after excluding the P-UTILI2 item, are shown in the following table:

Cronbach's alpha coefficient was applied to assess the reliability of the questionnaire. Cronbach's alpha is a statistical tool that quantifies, on a scale of 0 to 1 , the reliability of the data in a questionnaire. Some authors, such as [28], state that, to reflect acceptable reliability, Cronbach's Alpha must have values between 0.60 to 0.70 which is considered as the lower limit of acceptability However, it recognizes that this value is not an absolute standard, admitting that alpha values below 0.60 can be accepted, if the research is exploratory "in nature" [28]. However, [22] reliability can be considered in several levels of reliability: 0.81 to 1.0 - almost perfect; 0.61 to 0.80 substantial; 0.41 to 0.60 - moderate; 0.21 to 0.40 reasonable and Cronbach's alpha coefficient, found in this research, was 0.122 for variables classified as SIST-Q and Q-INFO and 0.513 for variables classified as P-UTILI. Therefore, for the variables classified in SIST-Q AND Q-INFO, the reliability was considered low. For the variables classified in P-UTILI, they were considered moderate, taking as a parameter the studies by [22]. The result may be related to the size of the sample presented [17].

In sequence, according to table XI, the suitability of the sample was tested, represented by the Bartlett sphericity test and the Kaiser-Meyer-Olkin index (KMO). These measures verify if the factor analysis method can be used and whether it is an adequate method for the research purposes. The test results are arranged as following table:

TABLE VI: SAMPLE SUITABILITY TESTING

\begin{tabular}{lcc}
\hline \hline \multicolumn{3}{c}{ KMO and Bartlett test } \\
\hline Kaiser-Meyer-Olkin measure of sampling adequacy. & 0.385 \\
\hline \multirow{2}{*}{ Bartlett's sphericity test } & Approx. Chi-square & 10,477 \\
\cline { 2 - 3 } & gl & 15 \\
\cline { 2 - 3 } & Significance & 0.789 \\
\hline
\end{tabular}

The concept of suitability, according to Hair et al., are acceptable values between 0.5 to 1.0 , therefore below 0.5 indicates that the factor analysis is unacceptable [34]. The authors Kaiser \& Cerny indicate that, for the adequacy of adjustment of a factor analysis model, the KMO value must be greater than 0.8. The aforementioned results, Bartlett and Measure's sphericity test, with a result of 0.789 and a sample adequacy of 0.385 , suggests that the sample of this research is inadequate [35].

At another time, according to table VII, the frequencies of
SIST-Q and Q-INFO were analyzed together, as they have the same categories of responses classified as 2 (yes), 1 (no), 0 I do not know how to evaluate:

TABLE VII: SUMMARY OF VALID CASES - SIST-Q / Q-INFO

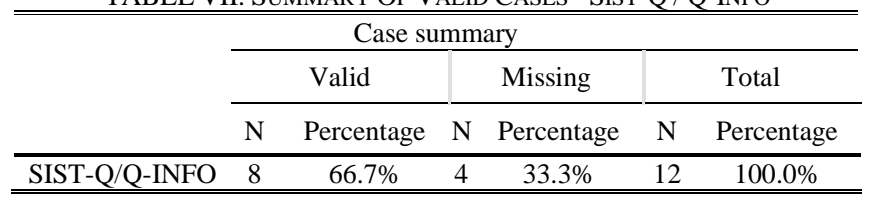

Table VIII shows how many people answered the variables SIST-Q and Q-INFO in the questionnaire. Missing cases are researched that did not respond to any of the variables. Therefore, out of the total of twelve questionnaires applied, eight answered the questions.

TABLE VIII: SIST-Q / Q-INFO FREQUENCY

\begin{tabular}{lccc}
\hline \hline & \multicolumn{2}{c}{ Responses } & Percentage \\
\hline \multirow{2}{*}{ SIST-Q/ I CANNOT EVALUATE } & 11 & $13.8 \%$ \\
\cline { 2 - 4 } & NO & 12 & $15.0 \%$ \\
\cline { 2 - 4 } & YES & 57 & $71.3 \%$ \\
\hline \multicolumn{2}{c}{ Total } & 80 & $100.0 \%$ \\
\hline \hline
\end{tabular}

The result of the analysis of the frequency of the variables SIST-Q01 to P-UTILI1 showed that there were 27 responses in the "useful" category, with $56.3 \%$ of the total responses and 21 responses in the "very useful" category, with $43.8 \%$ of the total answers. As there were no answers for the categories "indifferent", "not very useful" and "not useful", the system ignored these data.

The result presented shows that, in the interviewees 'perception, the Cost Information System (CIS) is considered useful, with users' satisfaction being measured in a positive way.

TABLE IX: SUMMARY OF CASES OF P-UTILI VARIABLES

\begin{tabular}{|c|c|c|c|c|c|c|}
\hline & \multicolumn{2}{|r|}{ Valid } & \multicolumn{2}{|r|}{ Missing } & \multicolumn{2}{|c|}{ Total } \\
\hline & $\mathrm{N}$ & Percentage & $\mathrm{N}$ & Percentage & $\mathrm{N}$ & Percentage \\
\hline P-UTILI2 & 8 & $66.7 \%$ & 4 & $33.3 \%$ & 12 & $100.0 \%$ \\
\hline
\end{tabular}

Table IX is showing how many people answered the PUTILI variables in the questionnaire. Missing cases are researched that did not respond to any of the variables. Therefore, out of the total of twelve questionnaires applied, eight answered the questions.

TABLE X: P-UTILI FREQUENCY

\begin{tabular}{|c|c|c|c|}
\hline \multicolumn{4}{|c|}{ P-UTILI2 Frequencies } \\
\hline & & Number of responses & Percentage \\
\hline \multirow{2}{*}{ P-UTILI2a } & USEFUL & 27 & $56.3 \%$ \\
\hline & VERY USEFUL & 21 & $43.8 \%$ \\
\hline Total & & 48 & $100.0 \%$ \\
\hline
\end{tabular}

The result of the analysis of the frequency of the PUTILI02 to P-UTILI07 variables showed that there were 27 responses in the "useful" category, with $56.3 \%$ of the total responses and 21 responses in the "very useful" category, with $43.8 \%$ of the total answers. As there were no answers for the categories "indifferent", "not very useful" and "not useful", the system ignored these data.

The result demonstrates that, in the interviewees 'perception, the Cost Information System (CIS) is 
considered useful, with users' satisfaction being measured in a positive way.

In a second step, the overall consistency of the Cost Information System (CIS) assessment was assessed using the Chi-Square test, which is a classic test of goodness of fit that assesses whether the model fits the data observed in the same extension of the equivalence that exists between the covariance matrix generated by the model and the observed covariance matrix [31]. The main results for the Chi-Square Test for Association were interpreted, in order to analyze whether the association between variables was statistically significant.

According to the theory, a significance level of 0.05 indicates a $5 \%$ risk of concluding that there is an association between variables when there is no real association. The results obtained according to the following Table:

TABLE XI: TEST STATISTICS SIST-Q / Q-INFo / P-UTILI

\begin{tabular}{|c|c|c|c|c|c|c|}
\hline & SIST-Q3 & Q-INFO1 & Q-INFO4 & \multicolumn{3}{|c|}{ Q-INFO5 } \\
\hline Chi-square & $0.125 \mathrm{a}$ & $2.156 \mathrm{a}$ & $4,500 \mathrm{a}$ & \multicolumn{3}{|c|}{$2.156 a$} \\
\hline gl & 2 & 2 & 2 & \multicolumn{3}{|c|}{2} \\
\hline \multirow[t]{2}{*}{ Significance } & 0.939 & 0.340 & 0.105 & \multicolumn{3}{|c|}{0.340} \\
\hline & P-UTILI2 & P-UTILI3 & P-UTILI4 & P-UTILI5 & P-UTILI6 & P-UTILI7 \\
\hline Chi-square & $0.021 \mathrm{a}$ & $0.021 \mathrm{a}$ & $0.021 \mathrm{a}$ & $0.333 \mathrm{a}$ & $0.021 \mathrm{a}$ & $1.687 \mathrm{a}$ \\
\hline gl & 1 & 1 & 1 & 1 & 1 & 1 \\
\hline Significance & 0.885 & 0.885 & 0.885 & 0.564 & 0.885 & 0.194 \\
\hline
\end{tabular}

In analysis of the constructs, the Chi-square of the items System Quality (SIST-Q), Information Quality (Q-INFO) and P-UTILI1, which were analyzed together because they have the same parameters, varied between 0.125 to 4.5 and, p- value, or significance, varied between 0.105 and 0.939 , being significant for the items Q-INFO1, Q-INFO4 and QINFO5. We conclude that in this first analysis, only SISTQ3 has no significance and, therefore, is the only item of the SIST-Q and Q-INFO constructs in which the sample is adherent, which confirms the expected model and that the observed is very close to the expected.

In the Perceived Utility (P-UTILI) construct, the Chisquare varied between 0.021 and 1.687 and the p-value, or significance varied between 0.194 and 0.885 , with no significance for the items P-UTILI2, P-UTILI3, P-UTILI4, P-UTILI5 and P-UTILI6. This research concludes, therefore, that in these items the sample is adherent, observations are close to the expected results and does not conform to the expected model. Only the item P-UTILI7 had significant significance ( $p$-value), concluding that, in this item, the observation is not close to the expected and, consequently, P-UTILI7 is not adequate and does not confirm the expected model.

According to Hair et al, the factor analysis should not be performed with a sample with less than 50 observations and, preferably, the sample should be 100 or more. The minimum is to have five times the number of variables to be analyzed [28]. The sample size of the present research, according to the aforementioned authors, does not seem adequate and is not in accordance with the literature. Despite having a sample considered insufficient, this research considered it relevant to test the model with a smaller sample with an aim to verify what was stated by the authors.

\section{G. Evaluation Through Interview}

The interview with the head accountant of the Credit Institution and Construction of Houses for Navy Employees (federal autarchy) was carried out at the organization's facilities, through a single meeting. We opted for the recorded and transcribed interview with the manager responsible for the Cost Information System in the Municipality using open questions.

For the transcription of the interview, the recommendations of [36] were used, which divides the transcription process as one of the phases of the interview that he classifies in three stages: the first consists in the elaboration of a script; the second phase in conducting the interview; and the third phase is transcription [36]. The survey with the workforce of the federal autarchy found, through responses to the questionnaires, that most of the interviewees were aware of the existence of a performance indicator in the Organization to assess the results of the CIS. Relevant parts of the transcribed interview are shown in the Table XII.

\section{H. Non-Participant Observation}

It was observed that the workforce's performance in relation to the CIS is limited to the insertion of data in the act of settlement of invoices. When the sectors make any type of material purchase, the cost centre is informed in the body of the note so that the costs can be classified in the system.

It is relevant to note that the main system used by the Finance Department is the IFAS, realizing the need for greater familiarization with the CIS by all components of the sector's workforce and especially the managers who do not have access to the CIS, but that the information extracted from the system is relevant for decision making in cost management.

\section{Performance Indicator Suggestion}

The development of a performance indicator was considered a critical factor for this impact assessment of the Cost Information System of the Federal Autarchy.

The Autarchy profile on the National Transparent Treasury page of the National Treasury Secretariat (NTS) was analyzed to understand how costs are classified and managed by the organization and, also, for the construction of the performance indicator.

It was observed that costs are classified by cost items and are subdivided into controllable and non-controllable. The performance indicator was constructed based on the controllable costs by Federal Autarchy. For the construction of the proposed performance indicator the technique was used the 6Es Performance System. Also, it was used the system already used by the Federal Autarchy for the adoption of new indicators. The effort (economy, execution and excellence) and the result: efficiency, effectiveness and effectiveness were considered. 
TABLE XII: EVALUATION THROUGH INTERVIEW

\begin{tabular}{|c|c|c|}
\hline Question & Answer & Finding/argument \\
\hline $\begin{array}{l}Q \text { - Do you have a performance } \\
\text { indicator that can make an } \\
\text { assessment of how the system } \\
\text { works? }\end{array}$ & $\begin{array}{l}\text { E1 - [...] at the moment, we have nothing developed, but it is also } \\
\text { nothing that cannot be developed. As a cost center it started to be } \\
\text { implemented effectively this year, in } 2019 \text { because Navy Finance } \\
\text { Directorate (NFD) itself was still updating the standards it was } \\
\text { improving to be like this, so from } 2020 \text { we will have enough } \\
\text { numbers to possibly use them indicators, in spreadsheets, finally, } \\
\text { in reports, of course, as from } 2020, \text { without a doubt, it is an } \\
\text { important tool to assist in the control, in the monitoring, but today, } \\
\text { at this moment we do not have it. }\end{array}$ & $\begin{array}{l}\text { The result of the survey with the workforce } \\
\text { suggest that most responded that they were aware } \\
\text { of the existence of a performance indicator in the } \\
\text { Organization that evaluated the Information } \\
\text { System of Costs (CIS). According to the } \\
\text { transcript, it is relevant to note that it was stated } \\
\text { that there is no performance indicator for CIS } \\
\text { evaluation. }\end{array}$ \\
\hline $\begin{array}{l}Q \text { - And do you think the } \\
\text { workforce will be prepared to } \\
\text { manipulate this information and } \\
\text { be able to extract management } \\
\text { information that improves } \\
\text { management? Will the } \\
\text { workforce be able to prepare to } \\
\text { extract the information? }\end{array}$ & $\begin{array}{l}\text { E1 - [...] and I do not say prepared to release information, but she } \\
\text { is able to inform when the notes are released, when she goes over } \\
\text { the documents so that the costing area makes the correct entries, } \\
\text { according to guidance contained in the internal order and, } \\
\text { possibly later on, lectures on the subject will be held. So, the } \\
\text { workforce will be in a position to know that she has taken the } \\
\text { document in which she needs to classify at the correct cost, she } \\
\text { will be able to access information. }\end{array}$ & $\begin{array}{l}\text { The result of the survey with the workforce } \\
\text { suggest that most responded that they had already } \\
\text { participated in an event such as courses, lectures } \\
\text { or seminars on the CIS. In the interview, as } \\
\text { transcribed, it was replied that the workforce is } \\
\text { not yet able to use all the features of the Cost } \\
\text { Information System. }\end{array}$ \\
\hline $\begin{array}{l}Q \text { - As the leadership, the top } \\
\text { management of Caixa de } \\
\text { Construções uses this } \\
\text { information? Or if it is not used } \\
\text { yet, in the future it will be able } \\
\text { to be used better? Does top } \\
\text { management today know the } \\
\text { features of the CIS? And if you } \\
\text { don't know, in the future is } \\
\text { there a forecast that they will } \\
\text { have a greater knowledge of } \\
\text { this tool? }\end{array}$ & $\begin{array}{l}\text { E1 - [...] As in 2019, so to speak, in quotation marks, it was a year } \\
\text { of learning about CIS, which even the department itself, in that } \\
\text { year that it started to develop the documents, set up this } \\
\text { apportionment spreadsheet, exchanged figures there with the } \\
\text { Finance Directorate, which is also improving there in these } \\
\text { processes. So, today, top management has this knowledge of cost } \\
\text { systems, but it still does not really know how to operate. [...] the } \\
\text { goal is that in the future the information obtained in the system } \\
\text { facilitate decision-making for senior management [...]. Anyway, so } \\
\text { the trend here in the future really is for top management to make } \\
\text { full use of information from cost centers. Today, it is still not } \\
\text { entirely possible. }\end{array}$ & $\begin{array}{l}\text { The CIS's objective is being to support the public } \\
\text { management decision-making process [15]. It is } \\
\text { relevant to note that, according to the transcript, } \\
\text { managers still do not use the cost information } \\
\text { system (CIS) features for decision making. It is } \\
\text { relevant to note that the manager mentions that } \\
\text { the CIS needs improvement. }\end{array}$ \\
\hline
\end{tabular}

The costs were classified by cost items and subdivided into controllable and non-controllable. The performance indicator was constructed based on the controllable costs by The Federal Autarchy.

For the formulation of indicators, four steps were necessary in sequence: identification of the dimension and the object of measurement, establishment of the indicator and its consequences, validation of the indicator, and construction of a formula, target and score (determination of values). It was used in the research a form which already constitutes the model adopted in the Federal Autarchy to present performance indicators. The following equation expresses the formula for the Controllable Costs indicator (GCC) as follows:

\section{$\sum$ of controllable cost items with reduction $=X 100$ Total controllable cost items}

The Controllable Costs Indicator is equal to (sum of controllable cost items with reduction, divide by Total controllable cost items and multiplied by a hundred.

In the construction of the indicator, it was necessary to assess compliance and pertinence with the process to be measured and if it meets the requirements of the same: the indicator is valid to express the expected results; the indicator is directly related to the proposed objectives; the data comes from reliable sources; it is measurable; enough to express the dimensions involved; considers the territorial dimension, when necessary; expresses transversal issues, when they exist; the inherent limitations of the indicator were considered.

The following table shows the indicator proposed by this survey for Federal Autarchy, using the form template already adopted by the Organization for the management of its performance indicators:

TABLE XIII: KEY PERFORMANCE INDICATOR (KPI)

\begin{tabular}{ll}
\hline \hline (GCC) Controllable Costs Management \\
\hline Effort & Economics \\
\hline Indicator type (result) & Efficiency \\
\hline What measures & $\begin{array}{l}\text { Impact of Strategic Cost Management on the } \\
\text { Results }\end{array}$ \\
\hline Who measures & Accounting sector \\
\hline Information Users & $\begin{array}{l}\text { Presidency, Executive Board, Finance } \\
\text { Department }\end{array}$ \\
\hline frequency & Semester \\
\hline Where to measure & $\begin{array}{l}\text { Federal Government Cost Information } \\
\text { System (CIS) }\end{array}$ \\
\hline Management information & $\begin{array}{l}\text { Check if the cost management through the } \\
\text { CIS is generating positive results for the } \\
\text { Municipality }\end{array}$ \\
\hline Scope of Measurement & Analysis at a Critical Analysis meeting \\
\hline Formula for calculation & $\begin{array}{l}\text { ( } \text { of controllable cost items with reduction } \\
\text { / Total controllable cost items) x 100 }\end{array}$ \\
\hline Goal & $\begin{array}{l}\text { 2020 - 2021 - 2022 - 2023 - 2024 } \\
\text { Percentage reduction of x, xx\% - per quarter }\end{array}$ \\
\hline Comparative framework & $\begin{array}{l}\text { Analysis at a Critical Analysis meeting } \\
\text { (The smaller the better) }\end{array}$ \\
\hline \hline
\end{tabular}

\section{SYNTHESIS}

The benefits of the Cost Information System (CIS) in the Credit Institution and Construction of Houses for Navy Employees (federal autarchy) will only be obtained if the workforce and managers are able to use the program efficiently and effectively. The purpose of the CIS is to assist the organization in the decision-making process for the allocation of resources and in the acquisition of products and services more efficiently. The implementation of the CIS at federal autarchy started in 2017 and as of September 2019 it was already in operation. The completion of the CIS implementation was formalized with the insertion of the information organized by cost center when the invoice is 
launched in the Integrated Financial Administration System (IFAS).

To assess the use of CIS by the workforce, data were collected from 2015 to 2019. For this assessment the methodological instruments were used: questionnaire, interview and on-site observation.

Information on costs was also made available on the National Transparent Treasury page of the National Treasury Secretariat (NTS). These made it possible to compare the evolution of costs year after year. This analysis has been carried out from 2015 to 2019. Information for the year 2020 has not yet been updated by the NTS.

Additionally, a performance indicator was suggested to assess the impact of the Caixa de Construções Cost Information System. The purpose of this study was not to evaluate this indicator.

The verification of the impact of the Cost Information System (CIS) on the cost management of Caixa de Construções was carried out in a qualitative way, through the verification of statistical data extracted from the website of the Secretariat of the National Treasury (NTS), the report of management of the Institution and the perception of the components of the federal autarchy workforce, directly involved in the process of calculating costs, accounting and financial execution, through interviews and application of a research form.

The process of implementing the Cost Information System (CIS) in the Credit Institution and Construction of Houses for Navy Employees Federal Autarchy, began in 2017 with the supervision of the Navy Finance Directorate (NFD), and was only concluded from September 2019, with the insertion of the information organized by cost center in the act of launching the invoice in the Integrated Financial Administration System (IFAS).

\section{A. Impact Assessment of the Cost Information System}

The federal autarchy' Financial Department is responsible for accounting, financial execution, treasury, insurance management and for managing the Federal Government's Cost Information System (CIS). Five out of the nine workforce responded to the survey. The supervision of federal autarchy is carried out by the Directorate of Finance of the Navy (NFD), a military organization belonging to the General Secretariat of the Navy and which exercises, among other competences, those of internal control, central accounting body, personnel payment and Brazilian Navy cost system. In order to measure more robustness to the research, questionnaires were sent to the cost sector of NFD, of the seven components of the cost sector workforce.

The questionnaire was sent between the months of December 2019 and March 2020. Weekly reminders were sent automatically by the system to the mailboxes of the workforce components who did not answer the questionnaire sent. The tool used to send the survey questionnaires was the Survey administration application, and Google Forms.

\section{B. Analysis of Cost Data Extracted from the Cost Information System (SIC)}

This paper analyzed cost information from the Credit Institution and Construction of Houses for Navy Employees,
Federal Autarchy, extracted from the website of the National Treasury Secretariat (NTS). It was not possible to conclude in the interview with the manager, in the answers to the questionnaire applied to the components of the workforce involved with the Cost Information System (CIS), or in the non-participant observation, the use by the federal autarchy management of the cost information generated by the NTS website.

The functionality, usability and usefulness of CIS cost information are variables that can assist Caixa de Construções managers in controllable cost items and the evolution of these costs over several periods. The information below was extracted from the CIS and compiled to provide an overview of the costs incurred between the 2015 and 2019 periods.

Analyzing the information from the CIS, it is possible to conclude that there is a reduction in most of the cost items, in relation to the previous year, mainly in the costs referred to in public management as "compulsory or administrative", such as, for example, administrative support and electricity.

The cost information provided by the National Treasury Transparent page, of the National Treasury Secretariat (NTS), makes it possible to compare the evolution of costs in one year compared to the previous year, from 2015 to 2019. Information for the year 2020 it has not yet been updated by the NTS, which are inserted by the General Services Administrative Unit) at the time of the registration of the invoice in IFAS. Results by cost items, compared to a given year with the previous year. The indices suggest lower costs for most controllable cost items, as shown in the following table:

TABLE XIV: PERCENTAGE VARIATION IN COSTS

\begin{tabular}{|c|c|c|c|c|}
\hline \multirow{2}{*}{ Cost Items } & Variation & Variation & Variation & Variation \\
\hline & $15 / 16$ & $16 / 17$ & $17 / 18$ & $18 / 19$ \\
\hline Water and sewage & - & $27.94 \%$ & $-14.47 \%$ & $-17.36 \%$ \\
\hline $\begin{array}{l}\text { Administrative } \\
\text { support }\end{array}$ & - & $127.08 \%$ & $1.15 \%$ & $-35.54 \%$ \\
\hline $\begin{array}{l}\text { Other Controllable } \\
\text { Costs }\end{array}$ & $-102.60 \%$ & - & - & - \\
\hline $\begin{array}{l}\text { Other Third-Party } \\
\text { Services }\end{array}$ & $151581.51 \%$ & $541.68 \%$ & $-12.84 \%$ & $78.64 \%$ \\
\hline $\begin{array}{l}\text { Other Building } \\
\text { Services }\end{array}$ & - & $32.67 \%$ & $-11.44 \%$ & $-14.84 \%$ \\
\hline Electricity & - & $4.61 \%$ & $3.96 \%$ & $-12.45 \%$ \\
\hline Cleaning & - & $57.19 \%$ & $-4.45 \%$ & $-9.33 \%$ \\
\hline Consumables & $7.62 \%$ & $17.57 \%$ & $-29.13 \%$ & $12.75 \%$ \\
\hline Active Staff & $-11.00 \%$ & $-26.14 \%$ & $-9.19 \%$ & $-1.12 \%$ \\
\hline $\begin{array}{l}\text { Specialized } \\
\text { Technical Services }\end{array}$ & - & $105.17 \%$ & $-34.08 \%$ & $-10.98 \%$ \\
\hline $\begin{array}{l}\text { Information } \\
\text { Technology }\end{array}$ & $698.97 \%$ & $4401.23 \%$ & $35.88 \%$ & $32.40 \%$ \\
\hline Telephony & - & $-19.37 \%$ & $-22.66 \%$ & $-51.89 \%$ \\
\hline $\begin{array}{l}\text { Other Non- } \\
\text { Controllable Costs }\end{array}$ & - & $26.22 \%$ & $4.42 \%$ & $-7.26 \%$ \\
\hline $\begin{array}{l}\text { Inactive Staff / } \\
\text { Pensioners }\end{array}$ & $-98.89 \%$ & $24.91 \%$ & $6.53 \%$ & $2.11 \%$ \\
\hline $\begin{array}{l}\text { Not controllable } \\
\text { Exercise Expenses } \\
\text { Back. }\end{array}$ & $0 \%$ & $0 \%$ & $0 \%$ & $0 \%$ \\
\hline $\begin{array}{l}\text { Not controllable } \\
\text { Depreciation. } \\
\text { Amort. Exhaustion }\end{array}$ & $0 \%$ & $0 \%$ & $0 \%$ & $-12.36 \%$ \\
\hline Total & $-94.74 \%$ & $84.28 \%$ & $1.09 \%$ & $-0.02 \%$ \\
\hline
\end{tabular}


C. Result of the hypothesis presented by the HypotheticalDeductive Method

The hypothetical-deductive method was introduced to science by Sir Karl Raymund Popper. This author proposed a method that aimed to settle the duality between induction versus deduction, or better, between empiricism versus rationalism, until then existing in science [37]. According to [39], science is hypothetical and provisional, and not a definitive knowledge as the empiricists supposed. The method that Popper proposed was supposed by him to be unique, since it overcame pure rationalism and empiricism. According to [37], Popper's method can also be called "trial and error elimination method". The hypothetical-deductive method consists of checking a problem, gaps or contradictions in some previous knowledge or in existing theories. From these variables, conjectures are formulated, solutions or hypotheses; these, in turn, are tested in what Popper called the forgery technique. The falsification can be done, among other ways, through experimentation or analysis of statistics. After analyzing the results, the conjectures, solutions or hypotheses previously elaborated are evaluated, which can be reputed (rejected) or corroborated [37].

The conclusion of the hypothesis, in a qualitative way, was formed by information related to facts and data from the following sources: research form, interview and nonparticipant observation.

Fact to be verified: the variables of the Cost Information System (CIS), classified by this work in System Quality (SIST-Q), Information Quality (Q-INFO) and Perceived Utility (P-UTILI) generate positive effect in decision making in the most efficient allocation of expenses at federal autarchy.

Findings: the analysis begins by studying the facts found and detections to confirm their relevance in relation to the research objectives. The relevance is given by the answer to the questions: a) information collected in excerpts from the interview with the manager responsible for the Cost Information System and; b) according to item 4.3.6 and, of the non-participant observation [37].

It was observed by this research the CIS is not yet monitored by a performance indicator and does not generate cost savings for cost management because it is not used by managers prior to the decision to purchase products and services. Therefore, it was concluded that: a) the system is not functional, as it does not generate results for the decision-making process; b) it was observed that the workforce's performance in relation to the CIS is limited to the insertion of data in the act of settlement of invoices.

\section{CONCLUSION}

The Case Study of the impact of the Federal Government Cost Information System (CIS) showed that the studied system was fully implemented in the Federal Autarchy as of September 2019.

It was found, in the analysis of the variables, through the Chi-square tests that, although small, the sample is adherent, which confirms the expected model and that the observed is very close to the expected.

Additionally, it was concluded that the system is relevant and has parameters consistent with the activities of public management and is assessed by the workforce as functional, useful and having accuracy in the information generated. This Cost Information System is not yet monitored by a performance indicator and does not generate cost savings for cost management because it is not used by managers prior to the decision to purchase products and services. Therefore, it was concluded that the system is not functional, as it does not generate results for the decision-making process [37].

The research applied through Google Forms and the interview with the head accountant of the federal autarchy were designed to respond to the parameters of system quality, information quality and customer satisfaction. Most respondents consider that the system is useful for decision making, that it is easy to use and that it is meeting the purpose for which it was developed. Because the sample is very small in scale, further research with a larger population will be necessary for the impact to be properly assessed.

In order to achieve reliable results in the analysis of the impact of the Cost Information System, it is suggested that further research be developed considering the following points: (1) application of the impact assessment model in other organizations in the form of case studies for check its robustness; (2) adapt the methodology for use with other management aid methods; (3) create a database that presents the different criteria used in the evaluation of information systems; (4) consider the quality, usability and user satisfaction when assessing information systems.

We tried to understand what the bases of the cost system in public management entities are and how the Cost Information System was structured. Subsequently, we sought to assess the importance of cost management for decision making and how it can be functional in federal public management.

The Cost Information System (CIS) being used will play an important role in the decision-making process within the public administration. To achieve this, it is necessary that managers and users of the system make the correct application of the CIS and that the system is constantly evaluated by indicators that showed the improvements or needs for correction in the system.

Finally, it is expected that the Caixa de Construções de Casas para o Pessoal da Marinha (Credit Institution and Construction of Houses for Navy Employees) will manage the use of the CIS to make it functional, usable and useful, adopting the indicator suggested by this research "Controllable Cost Management", after its validation and, monitor the results in cost management, in order to manage the available resources in the best way. It is also suggested that new research be developed to adapt the system to the needs of organizations.

\section{REFERENCES}

[1] FILARDI FF, FREITAS, IRIGARAY, AYRES AB (Im)Possibilidades da aplicação do Modelo de Excelência em Gestão Pública (MEGP). Revista de Administração Pública. 2016 Jan/Fev; 50(1).

[2] MAUSS, V.; DIEHL, C. A.; BLEIL, C. A Gestão de Custos Como Instrumento da Eficiência Pública $\mathrm{N}^{\mathrm{o}}$ Revistra Eletrônica da Administração e Turismo, v. 6, n. 3, p. 595-609, janeiro-junho 2015. ISSN ISB 2316-5812. 
[3] BERTÓ, J.; BEULKE, R. Gestão de Custos. São Paulo: Saraiva, 2014.

[4] SILVA et al. The influence of public spending on the efficiency in the use of revenue in the units of the Brazilian federation. Society, Accounting and Management, pv 14, n.1, pp 136-157, 2019.

[5] WIEMER APM, RIBEIRO DC. Custos no Serviço Público. Congresso USP de Controladoria. 2004.

[6] SANTOS, W. V. Sistema de Informações de Custos do Governo Federal: Modelo Conceitual. Revista CONSAD, 2011.

[7] BORGES, B.; MARIO, P. D. C.; CARNEIRO, R. A implementação do Sistema de Custos Proposto pelo Governo Federal: Uma análise sob a Ótica Institucional. Revista da Administração Pública (RAP), Rio de Janeiro, v. 47, n. 2, p. 469-491, 2013. ISSN ISSN 0034-7612.

[8] STN, Secretaria do Tesoura Nacioanl S. Manual de Informações de Custos do Governo Federal. Transparent Treasure, 2018. Disponivel em:

<https://sisweb.tesouro.gov.br/apex/f?p=2501:9:9:P9_ID_PUBLICA CAO:25901>. Acesso em: 11 fevereiro 2020.

[9] CCCPM, Caixa de Contruções de Casas Para o Pessoal da Marinha. Relatório de Gestão (Management Report) de 2019. Caixa de Construções de Casas para o Pessoal da Marinha. Rio de Janeiro, p. 1 81. 2019

[10] BLOCHER, E. J. et al. Gestão Estratégica de Custos 3a. Ed. 3a. ed. São Paulo: MC Graw Hill, 2006.

[11] RIBEIRO, R. M. et al. Gestão Estratégica de Custos em Organização do terceiro Setor: O Caso do Lar Escola da Criança de Maringá. XXII Congresso Brasileiro de Custos, 11 novembro 2015.

[12] PORTER, M. E. Vantagem competitiva. [S.1.]: Campus Ltda., 1990

[13] REZENDE, F.; CUNHA, A.; BEVILACQUA, R. Informações de Custos e Qualidade dos gastos Públicos Liçoes da Experiência Internacional. Revista da Administração Pública (RAP), Rio de Janeiro, v. 44, n. 4, p. 959-992, 2010. ISSN 1982-3134.

[14] STN, S. D. T. N. Portal de Custos do Governo Federal. Tesouro Nacional, 2017. Disponivel em: <https://www.tesouro.fazenda.gov.br/custos>. Acesso em: 30 maio 2019.

[15] SANTOS, W. V. Sistema de Informações de Custos do Governo Federal: Modelo Conceitual. Revista CONSAD, 2011.

[16] HARVEY, BH et al. Key Performance Indicators in Radiology: You Can't Manage. Elsevier, v. 45, n. 2, p. 115-121, March-April 2016 ISSN 10.1067.

[17] SANDES, D. S. T.; LOOS, M. J. Implementação de uma rotina de acompanhamento de indicadores de performance como base para a tomada de decisão. Exacta, Florianópolis, v. 17, n. 2, p. 1-16, 2019 ISSN 1983-9308.

[18] BRASIL, M. D. P. Gespública.gov.br. GESPÚBLICA, 2009 Disponivel em: <http://www.gespublica.gov.br/sites/default/files/documentos/guia_in dicadores_jun2010.pdf>. Acesso em: 02 abr. 2020.

[19] BALA, A.; HAJ, AK Key Performance Indicators (KPIs) in the Change Management of Public Administration. European Scientific Journal, February 2017. 278-283.

[20] DELONE, W. H.; MCLEAN, E. R. Information System Success: The Quest for The Dependent Variable. The Institute of Management Sciences, Março 1992. 60-95

[21] DELONE, W.; MCLEAN, E. The DeLone and McLean Model of Information Systems Success: A Ten-Year Update. Journal of Management Information Systems, Spring, v. 19, n. 4, p. 9-30, Março 2003. ISSN 11742-1 222.

[22] LANDIS, J. R.; KOCH, G. G. The Measurement of Observer Agreement for Categorical Data. jstor-org.ez2.periodicos. capes, $\mathrm{p}$. 159-174, março 1977.1 Disponivel em: <https://www.jstor.org/stable/2529310>. Acesso em: 27 maio 2020.

[23] KIDO, E. Y.; HIRAMA, K. Enegep_2008. Enegep_2008, 13-16 out. 2008. Disponivel em: <http://www.abepro.org.br/biblioteca/enegep2008 TN STO 07653 6_12102.pdf>. Acesso em: 1620192019.

[24] AMARAL, P. Camões, Instituto da Cooperação e da Língua, I.P Camões, Instituto da Cooperação e da Língua, I.P., fev. 2013 Disponivel em: <https://www.institutocamoes.pt/images/cooperacao/doc trabalho8 2013.pdf $>$. Acesso em: 1620192019

[25] BRUCKHAUS, T. et al. PORTAL DE PERIÓDICOS - CAPES/MEC IEEE Xplore, setembro 1996. ISSN 5377695. Disponivel em: $<$ https://ieeexplore-ieee-

org.ez2.periodicos.capes.gov.br/document/536456>. Acesso em: 29 20202020.

[26] BRUCKHAUS, T. et al. Software Escalation Prediction with Data Mining. Sun internal documentation, 2004. Disponivel em: <file:///D:/Projeto_mestrado/Disserta\%C3\%A7\%C3\%A3o/Software
\%20Escalatio\%20Prediction\%20with\%20data\%20mininsg_Bruckhau s.pdf $>$. Acesso em: 28 jan. 2020

[27] LUNDELL, B; LINGS, B. The 2G method for doubly-based assessment structures. Wiley on Line Library, 2003. ISSN https://doi.org/10.1046/j.1365-2575.2003.00154.x. Disponivel em <https://onlinelibrary.wiley.com/>. Acesso em: 13 jun. 2020.

[28] HAIR, et al. Análise Multivariada de Dados. 6. ed. Porto Alegre: Bookman, 2009.

[29] JUNG, C. F. Elaboração de Projetos de Pesquisa Aplicados a Engenharia de Produção. FACCAT, 11 jun. 2010. Disponivel em:<. Acesso em: 29 maio 2019

[30] PRODANOV, C.; FREITAS, E. C. D. Metodologia do Trabalho Científico. Rio Grande do Sul: Feevale, 2013.

[31] DUARTE, A. L. F.; VIEIRA, P. R.; SILVA, A. C. M. Avaliação de Escala para Mensuração da Eficácia de Sistema de Informação: Um Estudo com Análise Fatorial Confirmatória. GEINTEC, São Cristóvão, v. 5, n. 2, p. 1896-1999, 2015. ISSN 2237-0722.

[32] MONTGOMERY DC, RUNGER GC. Estatística Aplicada e Probabilidade para Engenheiros. 6th ed. GEN , editor. Rio de Janeiro: LTC; 2016.

[33] MOURA DV. Utilidade para testes de Significância. Dissertação de Mestrado. São Paulo: Universidade de São Paulo, Instituto de Matemática e Estatística; 2014.

[34] HAIR, F. et al. Multivariate Data Analysis with Readings. 2. ed. [S.1.]: Macmillan, v. II, 1987.

[35] KAISER; CERNY. Um Estudo de Uma Medida de Adequação de Amostragem para Matrizes de Correlação Analítica de Fatores. Pesquisa Comportamental Multivariada, v. 12, n. 1, p. 43-47, 1977. ISSN https://doi.org/10.1207/s15327906mbr1201_3.

[36] MANZINI, J. Considerações Sobre a Transcrição de Entrevistas. oneesp.ufscar, 2008. Disponivel em: <http://transcricoes.com.br/wpcontent/uploads/2014/03/texto_orientacao_transcricao_entrevista.pdf >. Acesso em: 29 abr. 2020.

[37] MARCONI MA, LAKATO EM. Fundamentos da Metodologia Científica. 7th ed. São Paulo: Atlas S/A; 2010.

[38] POPPER KR. A Lógica da Pesquisa Científica Paulo UdS, editor. São Paulo: Cultrix; 1975

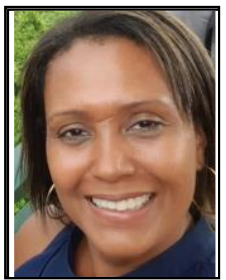

Patricia Santos is Graduated in Accounting sciences in 2000, Master Business Administration (MBA) in Accounting and Finance in 2003, and postgraduate Teaching in Higher Education in 2006. She is Leading Auditor of Quality Management, NBR ISO 9001:2000.

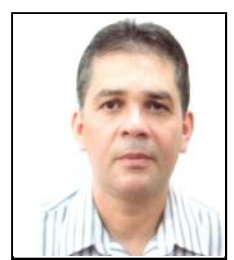

Marcelo Oliveira is an Adjunct Professor, Department of Production Engineering and membe of Master Program in Production Engineering, Federal University of Amazonas. He has published several Research Papers related to Engineering area.

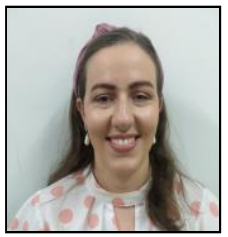

Gabriela Veroneze is an Adjunct Professor, Department of Production Engineering and member of Master Program in Production Engineering, Federal University of Amazonas. She has published several Research Papers related to Engineering area.

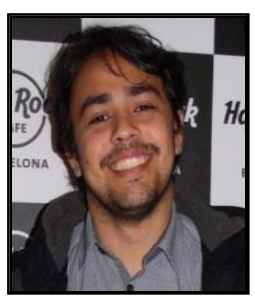

Marcelo Pereira is a Product Management Specialist in Eldorado Research Institute using lean/agile methodologies to develop new systems and manage collaborative teams 